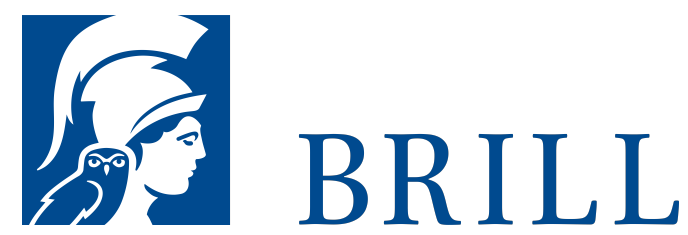

\title{
Zuschauen bei der chemischen Reaktion: Detektivarbeit mit Lasern und Massenspektrometern
}

\author{
Authors: Katharina Kohse-Höinghaus and Andreas Brockhinke \\ Die Nordrhein-Westfälische Akademie der Wissenschaften und \\ der Künste ist eine Vereinigung der führenden Forscherinnen \\ und Forscher des Landes. Sie wurde 1970 als \\ Nachfolgeeinrichtung der Arbeitsgemeinschaft für Forschung \\ des Landes Nordrhein-Westfalen gegründet. Die Akademie ist in \\ drei wissenschaftliche Klassen für Geisteswissenschaften, für \\ Naturwissenschaften und Medizin sowie für Ingenieur- und \\ Wirtschaftswissenschaften und in eine Klasse der Künste \\ gegliedert.
}

Mit Publikationen zu den wissenschaftlichen Vorträgen in den Klassensitzungen, zu öffentlichen Veranstaltungen und Symposien will die Akademie die Fach- und allgemeine Öffentlichkeit über die Arbeiten der Akademie und ihrer Forschungsstellen informieren.

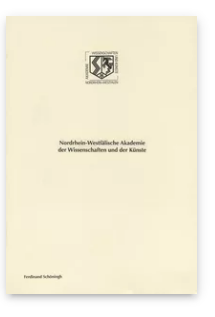

Pages: 46 Seiten Language:

German

Subjects:

History of

Science, History

Publisher: Brill |

Schöningh

Series:

Nordrhein-

Westfälische

Akademie der

Wissenschaften und der Künste -

Naturwissenschaften und Medizin,

Volume: 474

E-Book (PDF)

Released online:

O3 Feb $202 \mathrm{O}$

ISBN: 978-3-

657-76876-9

List price

USD $\$ 36.00$

Paperback

Publication date:

19 Aug 2009

ISBN: 978-3-

5०6-76876-6

List price

USD \$36.0o 
For more information see brill.com

Order information: Order online at brill.com +44330 333 0049 | customerservices@brill.com Submission information: brill.com/authors

Titles published by Brill | Fink, Brill | mentis or Brill | Schöningh: +49(o)715413279216| brill@brocom.de 